\title{
Third-Party Intervention in Asymmetric Conflict Resolution Pasar Raya Padang Post-Earthquake in 2009
}

\author{
Ikhsan Muharma Putra (Ikhsan@stkip-pgri-sumbar.go.id) ${ }^{1}$,Rinel Fitlayeni ${ }^{2}$, Marleni $^{3}$, \\ Afrizal $^{4}$, and Indraddin ${ }^{5}$ \\ ${ }^{1,2,3}$ Sociology Education Department of STKIP PGRI Sumatera Barat, Indonesia \\ ${ }^{4,5}$ Sociology, Faculty of Social and Political Sciences, Universitas Andalas, Indonesia
}

\begin{abstract}
After earthquake 30 September 2009 Raya Market Padang began to be disturbed. Padang City Government responded quickly with construction of an emergency store, but has Opposed by some traders because decreased profits and low visitors. This condition triggered a long conflict and has been going on for five years (2009-2014). Many efforts have been made by stakeholders to find a conflict resolution, so it is important to further elaborate who actor has become a third party facilitating asymmetric conflict resolution. Based on the findings, the parties who really are in the position of a third party is the DPRD of Padang City and KOMNASHAM RI. The DPRD of Padang is structurally in the position of the government, but its function is as a representative of the people in the government. This position makes the slices between the DPRD and the traders as the people (constituents) and slices with Padang City Government as executive of the city government. The intervention undertaken by the DPRD was Hearing to Raya Market traders, and involving their representatives at the hearing, the DPRD working meeting discussing the issues related in $2^{\text {nd }}$ Commission. Other interventions are controlling the rehabilitation and reconstruction process, and the realization of budgeting in APBD based on the needs of traders.
\end{abstract}

Keywords: Conflict Resolution, Market, Third Party.

\section{Introduction}

Market is one of an important part in the community institutions. The market can be seen not only as place and can also be seen as institutions that have value and norms. Some interesting things from a market is the presence of time and space [1]. It means the aspect of the space is a market place. A market is rendezvous the seller and buyer, there are transactions, exchanges, reciprocities, and various economic activities. Referring to the time when there is need and no, which are would affect in the market. Traditional markets also have two aspects, which mainly is a space for reconcilable of seller and buyer. Market facilities having a different value, depending on their function in economic activity. The market can also be seen point of view of conflict, where market is a place of conflict [2][3]. When a market is space and time are full of competitions or conflicts then market must be special attention from various parties. Many parties are involved, there are too many real and hidden interests. However as far as conflict is a conflict latent hence, the market will still be running as where it should be. But if the conflicts have shaped manifest such as the existence of protest, resistance, sabotage, destruction and others, then market function will did not run as intended. Raya Market Padang is one of the largest traditional markets in West Sumatra. Peak of the development was held during 1931-1970. At the time trade rapidly growing in the city, the construction of city hall in Raya market and stimulate the 
buildings shops and building market to the 1990s. The building of Raya Market is local asset which managed by city government. Management and orderliness facilitated by the market office for all problems related to the market. All of the social system in the market running by itself after all the process of market development and deals in every actor the market kept running.

The journey of Raya market deeply disturbed when earthquake 30 September 2009 was broken down and destructive building facilities in the market[4]. Almost all building is did not passed an eligibility for use as market facilities, so the recommendation for a number of buildings market has to rehabbed. After the earthquake, the city government issued a number policy related to the act of response disaster as rehabilitation and reconstruction of Raya Market. Essentially the constitution no $24 / 2007$ has set up how the action stakeholders related in time of disasters, including the act of and policies which should be made by local governments. According to research conducted by Firdaus, there were clashes prolonged when rebuild Raya market [4]. This conflict occurs between the Padang government as holders of authority with Raya market traders who are victims of the earthquake victims the right owner the stores, kiosks and shops [4][5].

In the case of the conflict after earthquake 30 September 2009 have occurred in a very long time where happened since 2009 up to peaked in 2010 and 2011 until 2014 is still taking place despite experiencing a decrease in scale conflict[5]. The protest done by the merchants become the foundation of the contention so that there must be a settlement effort. An effort to resolve and looking for a solution of the conflict have involved various parties especially the existence of the third side of the conflict. But which party should be said to be third-party? This question is essential to be answered in this study. So that it becomes important to do more depth study about intervention third parties in conflict resolution asymmetrical Padang Raya market post-earthquake in 2009. This paper presenting analysis asymmetric conflict between the government of the field after raya market traders, where any formal resolution done by various parties to look how the role of a third party in the resolution.

\section{Methods}

This writing resulting from research titled resolution conflict asymmetrical; case study conflict market raya Padang City after earthquake 2009. The research was done with a qualitative approach through collect the data in-depth interviews, documents and observation. The data in gather since February 2017 until June 2017 later in analysis with a model analysis adjustment Miles and Huberman (1992) .Data of the results of interviews, a document already in learn and the evidence field observations then analysed and reduced until then can be presented in the form of writings.

\section{Result and Discussion}

\subsection{Literatur review}

The conflict in the case of Raya market of Padang City after the quake 30 September 2009 have been examined in some study conducted by students, off researcher or lecturer. However, they are looked for different sides in the studies. Studies have initially still in the study organization, political and social movements as research conducted by Fidel in 2011. This study attempts to see contribution FWK (Forum Warga Kota) as social movement 
within the democracy in the city. He found that FWK is a great society organization where is a combination of some groups such as; victim traders earthquake in the city the highway, victims year 2007 that aid has not been given by the city government. Public mobilization is large enough joined FWK. But FWK is not contribute to the democracy in the city[6]. Other research was in 2011, which having a resemblance to research conducted by Fidel, however have a difference at the focus of his studies. Suryanto was about more deepen on strategic done by FWK in order to concern for municipal the policy in the development of stall emergency Raya market, Padang City. The finding was about is that there are some strategies done by FWK enforcing the interests of the formal; strategy and strategies demonstrations and violence. Two strategies was carried out by FWK and reflect where their demands granted by the city council city the field to form a team to solving problems and the redevelopment in the market town [7].

Similar far from previous research, Firdaus in 2011 also examine deeper related with conflict Raya market Padang City. This study focuses attention on protest disaster victims; study conflict disaster management in Raya market Padang City. In this study, Firdaus found that there are some important event that brings protests Raya market traders municipalities, especially related to the issued by City Government. These policies are; the construction of emergency kiosks that are considered to be injurious to traders. Development policy repeated inpres market I, II, III and IV considered traders would not in accordance with their needs traders and out of context disaster management, as well as the construction shops phase VII the second floor and iii requiring emptying on the $1^{\text {st }}$ floor. The form of protest done traders is through APPR (Asosiasi Pedagang Pasar Raya) Padang, forming joint strategy with FWK (Forum Warga Kota) and protest strategy together PBHI West Sumatra [4].

Still related to the conflict in Raya Market, Padang City that is the assessment conducted by Ira Ariesta in 2014. This study more focus on the discussion the role of women to the process of conflict resolution rehabilitation and reconstruction the market. In the analysis on the acts, there were several parties of women who owned a role in efforts conflict resolution of them are women from government agencies, women from NGO, some women activists from colleges and traders. However, those roles still quite low in the process of resolution. Of several action performed apparently women have been a victim of violence and a very in spare is when the negotiation process is in opposing sides when that moment women not involved [5].

Next study also involved in the study at conflict in Raya market Padang City which is assessment was conducted by Elvawati in 2015. Elvawati's , Padang City, study focused on model resolution conflict in local institutional with a case study Raya market. In this study Elvawati identify the causes of conflict with the findings the following first; the notion of emergency stall, secondly kiosks purchased, thirdly the number of kiosks built, fourthly the market building block 1 , the fifth, reconstruction inpres market II, third and fourth and fifth, the phase VII the floor 2 and 3[8]. The study also relevant to this review are review come to the scene and different contexts the role of the when conflict resolution. This study has been done by afrizal in his writings titled "Third-party Intervention in terminating Oil Palm Plantation Conflicts in Indonesia; A Structural Analysis”. In this study Afrizal formulate in the findings of her research the role of third parties in conflict resolution company palm with local communities. In his innovation there were several parties who contributed to mediate conflict. The parties are the local government and NGO. Both sides 
was having different results on efforts to resolution done. The local government is considered to have failed as the party being a mediator or third party to conflict resolution. Parties who are able to mediate NGO's success is to make an agreement between the company[9].

Several studies have been reviewed before it shows the conflict in the Raya market during the post-earthquake 30 September 2009. This study will see from different points of view where efforts to resolve conflicts that has been done in document and analysed it by the relationship structure between the government and the community. There are two layers of the different structures of the conflict, where the government as up structure and down for the community. For type conflict like this review of the actually potentially good for conflict resolution requires analysis to learning conflict resolution on to others context.

\subsection{The identified role in mediation Asymmetrical conflicts}

Parties identified has a role in conflict Raya market the post-earthquake 2009 is the first; warring parties are Raya market traders with municipal the City. Both; party role as an assistant. Third party; function as the working on ways the common ground on efforts to resolve conflicts. The warring parties on conflict Raya market is the party who is arguing the market traders oy the of Raya market disaster victims. A suit in regard to the municipal the next. There is disquiet, concerns the disaster victims with government policy not pro traders and community. Concerns would be the seeds of contention which the government issued policies are incompatible with the condition of the traders and alleged would be harmed traders. Relation a merchant by the city government at the time of this conflict being broken until making a difference of opinion. The Position does not balance in the power of the side of relationships between the government and traders herding traders to raise a force with involves several interest groups. Any of a large group the ones involved are Forum Warga Kota (FWK) [7]. The group also involved to strengthen traders is the representation of traders who joined to organizations traders, Aliansi Pedagang Pasar Raya (APPR). The alliance is being representation of traders to continue sound traders to the city government.

The second is the companion. Parties here is PBHI (Pusat Bantuan Hukum Indonesia) of west Sumatra. PBHI is legal aid organisations who work with his client to provide legal assistance on clients[11]. PBHI is non-profit organization that works on social care in the community involved in legal problem. The principle which is embraced in the process of mentoring is improving human resources who became his client. As for some of the approaches made by PBHI for conflict resolution the padang city was first; make improvements to human resources, second; with the strengthening of the Organization[11]. Two things are done by PBHI increasingly strengthening position PBHI as escort agency. PBHI not involved directly in the conflicts, but only provide protection, awareness, and strengthening organizations that perform resistance. On its activities have indeed PBHI alignments i.e. favours the client namely market Kingdom. And cannot be said to be a neutral party. In this case the Government of the city of Padang also cannot assume the PBHI as third-party neutral. Could have been in this position is a NGO's, the government, or Dewan Perwakilan Rakyat (DPR) [9][10]. Then a third party will conduct the mediation in an effort to accelerate the completion of the conflict. The deal that awakened from the results of the mediation will have the consent of the warring parties to a resolution of the conflict. In the case of a conflict the Padang earthquake 2009 identified there are two 
parties who acted as a third party. First is the KomnasHam and second is the DPRD Kota Padang.

\subsection{The DPRD Padang city as one of the third party}

The involvement of DPRD as one of the parties involved in the conflict resolution asymmetric the Padang earthquake was over the demands of the society in DPR as a representative of the people in the Government. The position of DPRD in principle is a balanced relationship on the position of this Asymmetrical conflict [12]. City council has main task of performing the surveillance on any policy conducted by the city. The council also has the right to the ratification of the proposed by the government of the . Is known in the individual in parliament loaded with interests, but interest in this context is also related to public interest as costituent council members. The council on the view the government is as a partner in running governance function. In the organization of the council and municipal in the same government structure. Those roles also the result of encouragement parties a companion namely west Sumatra PBHI to DPRD the keep running its function as an institution which oversees the administration city[12].

The city council the this, into a position assessed balanced by the warring parties . There are some activity in relation to the resolution involving city the council . The involvement of this could have been involvement council members as individuals or as representing institutional affairs council .Facilitating early done by central KomNasHam that unite representation of the warring parties by involving members of the council .Next to the hearing council and an audience with market traders highway by members of the council on 8 November 2011 until the results devoted through KomNasHam. In the case of burning occurring in the shelter in April 22, 2012 by the personnel of city, vice chairman directly the scene to perform investigation as well as silencer conflict that occurred on Raya market conflict. To the process of tension council budgeting process is struggling rehabilitation and reconstruction Raya market stay in the city [12]. Padang council also submitted discussion market cases conflict Raya market on council II commission who performs various functions including seek conflict resolution[12].

Mediation efforts to the process resolution was carried out by the field city council meetings and also council members individually or institution do investigation on various the case with Raya market. Government meeting town with traders in facilitation city council the at Padang city council to the point of a successful. Until in 2015, 2016 year and in 2017 rebuilding Raya market with the local and national budget.

\section{Conclusion}

Conflict in the Raya market Padang City post-earthquake in 2009 is one form of conflict asymmetrical. The warring parties basically structurally and power flaw. The government as parties who have power or power fight with traders who in structurally have no power to attempt conflict resolution of the role city Padang council is important in effort to resolution. The council has relation by the community as its constituents or the council is the representation of the community. And that city council has representatives function of council of the society sued to do their job as an institution control and escort the government. Here the supervisory function of DPRD to municipal the policy in line 
legislation and regulations. With the implementation of this parliament interests market traders of victims earhquake 2009 Raya market well accommodated.

\section{Acknowladgements}

We are very grateful because we can complete write this paper by a title "Third-Party Intervention in Asymmetric Conflict Resolution Pasar Raya Padang Post-Earthquake in 2009". This paper results from our study entitled asymmetric conflict resolution model (Case Study of Conflict Resolution of Pasar Raya Post-Earthquake in 2009) in 2017. This paper cannot be completed without the effort and co-operation from our group members, Group members' Ikhsan Muharma Putra, M.Si, Rinel Fitlayeni, S.Sos, M.A, Marleni, M.Pd. And Patners Groups members' Prof.Dr. Afrizal M.A and Dr. Indraddin, M.Si. we also sincerely thank our informan, our lecturer in STKIP PGRI Sumatera Barat for completed this research. The possibility of this article is still a lot less, and we beg in forgiveness. We welcome readers' criticism and suggestions for better paper.

\section{Reference}

[1] Damsar, Sosiologi Pasar, 1st ed. Padang: Laboratorium sosiologi, FISIP Universitas Andalas, 2005.

[2] Damsar, Sosiologi Ekonomi, 2nd ed. Jakarta: Raja Grafindo Persada, 2002.

[3] Sudarmo, "The Implications of Taditional Market Development for Governance of Conflic : an Experience of Klewer Market of Surakarta, Indonesia," J. Gov. Polit., vol. 7, no. 4, pp. 619-639, 2016.

[4] Firdaus, "Protes Korban Bencana; Studi Konflik Penanggulangan Bencana di Pasar Raya Kota Padang,” J. Ilmu Sos. Mamangan, vol. 1, no. 2, pp. 27-39, 2014.

[5] I. Ariesta, "Peran Perempuan Dalam Resolusi Konflik Rehabilitasi dan Rekonstruksi Pasar Raya Padang," J. Ilmu Sos. Mamangan, vol. 1, no. 2, pp. 41-51, 2014.

[6] Fidel, "Kontribusi FWK Sebagai Gerakan Sosial dalam Demokratisasi di Kota Padang," Andalas, 2011.

[7] Suryanto, "Strategi Kelompok Kepentingan Memperjuangkan Kepentingannya Dalam Konflik Forum Warga Kota (FWK) Terhadap Kebijakan Pemerintah Kota Padang," Andalas, 2011.

[8] Elvawati, F. Rinel, Marleni, Afrizal, and Indraddin, "Model Resolusi Konflik dalam Institusi Lokal, Studi Kasus Pasar Raya Padang Pasca Gempa 2009," Padang, 2015.

[9] Afrizal, "Third-Party Intervention in Terminating Oil Palm Plantation Conflicts in Indonesia: A Structural Analysis," SOJOURN, vol. 30, no. 1, pp. 141-172, 2015.

[10] H. Mail, O. Ramsbotham, and T. Woodhouse, Contemporary Conflict Resolution. Malden: Polity Press, 1999.

[11] Firdaus, "Dari Aksi Demonstrasi ke Negosiasi; Strategi Penguatan Gerakan Pedagang Korban Bencana Pasar Raya Padang Oleh PBHI Sumbar," in Konferensi Nasional Sosiologi V, 2016, pp. 2289-2296.

[12] I. M. Putra, F. Rinel, Marleni, Afrizal, and Indraddin, "Model Resolusi Konflik Asimetris (Studi Kasus Resolusi Konflik Pasar Raya Pasca Gempa tahun 2009)," Padang, 2017. 